\title{
Artificial neural network modelling approach of drying kinetics evolution for hot air oven, microwave, microwave convective and freeze dried pineapple
}

\author{
Tanmay Sarkar $^{1} \cdot$ Molla Salauddin ${ }^{1} \cdot$ Sudipta Kumar Hazra ${ }^{1} \cdot$ Runu Chakraborty ${ }^{1}$
}

Received: 14 April 2020 / Accepted: 27 August 2020 / Published online: 2 September 2020

(c) Springer Nature Switzerland AG 2020

\begin{abstract}
This study presents the dehydration characteristics of the drying of the pineapple slice. Hot air oven $\left(60^{\circ} \mathrm{C}\right)$, microwave $(100 \mathrm{~W})$, microwave convective $\left(600 \mathrm{~W}, 40^{\circ} \mathrm{C}\right)$ and freeze drying $\left(0.1 \mathrm{mbar},-40^{\circ} \mathrm{C}\right)$ of pineapple slice through artificial neural network (ANN) modeling approach (Backpropagation algorithm for feed-forward network). Considering the sample thickness of $0.15 \mathrm{~cm}$, effective moisture diffusivity is calculated. To study the reconstitution property of the product, the rehydration ratio is considered at $20^{\circ} \mathrm{C}, 40^{\circ} \mathrm{C}, 60^{\circ} \mathrm{C}$ and $80^{\circ} \mathrm{C}$. The microwave convective drying $(96 \mathrm{~min})$ is the fastest while the freeze drying is slowest $(20 \mathrm{~h})$. The coefficient of correlation through the ANN model for hot air oven, microwave, microwave convective and freeze dried sample are $0.99936,0.9994,0.99948$, and 0.99926 respectively. In terms of rehydration ratio, freeze drying (5.49) is found best followed by microwave (4.62), hot air (4.50), and microwave convective drying (2.00). At $80^{\circ} \mathrm{C}$ the coefficient of rehydration value attains the maximum of 0.969 for freeze dried sample, whereas the minimum value of 0.369 is observed at $20^{\circ} \mathrm{C}$ for the microwave-convective dried sample. From the observations obtain it may be stated that the ANN model predicts the dehydration kinetics adequately for the entire drying process. Freeze dried product appears to be the best in terms of reconstitution properties.
\end{abstract}

Keywords Pineapple · Artificial neural network · Dehydration kinetics · Rehydration ratio

\section{Introduction}

Pineapple (Ananas comosus) belongs to the Bromeliaceae family. It gains popularity owing to its juiciness, rich flavour, and health benefits. Being an abundant source of various nutrients like vitamins and minerals pineapple is a highly consumed sub-tropical fruit [1, 2]. Around 28 million tons of pineapple is produced globally, while 1415 thousand tons are produced by India, securing sixth position [3]. $85 \%$ of moisture content in pineapple makes it a perishable fruit [4]. Due to the unavailability of the proper preservation process, wastage is there for this climacteric fruit. Drying being a simple and effective process of preservation, practiced widely. As a post-treatment technique drying or dehydration is highly beneficial to pineapple. It helps in minimizing microbiological degradation by lowering the moisture content of the sample. Not only that but also in extending shelf life and making products available to customers all over the year [5]. Among various drying methods hot air oven, freeze, microwave, and microwaveconvective drying were opted to study the drying kinetics of pineapple slices. In the case of hot air drying evaporation of liquid occurs as a result of the circulation of heated air whereas microwave drying is found to be more suitable in drying pineapple as the use of electromagnetic energy shorten the drying time as well as produce quality product [6]. In order to have a lower drying period, microwaveconvective drying has been implemented successfully. On

$\triangle$ Runu Chakraborty, crunu@hotmail.com | 'Department of Food Technology and Biochemical Engineering, Jadavpur University, Kolkata, India. 
the other hand, freeze drying has also been effective in producing a dried product. In the characterization of drying kinetics and the effect of the quality parameter, theoretical and semi-theoretical mathematical modeling has been used for years. The artificial neural network (ANN) has been found more advantageous since it can precisely predict the drying kinetics as well as easily applicable to nonlinear processes [7]. This multi-layer interconnected neural net is designed based on the biological neural network. It has been utilised by many researchers in developing drying kinetics models as well as in predicting high precision results for fruits and vegetables $[6,8]$. Rehydration ratio is one of the key parameters to determine the quality of dehydrated products [9].

Though Nicoleti et al. [10], Agarry et al. [11], Rodríguez et al. [12] and Olanipekun et al. [4] studied pineapple slice drying kinetics in different conditions. Olanipekun et al. [4] and Izli et al. [13] examined the best-fitted model in explaining the drying characteristics as well as the comparison between fresh and differently dried (convective, microwave and freeze drying) pineapple in various aspects like colour, total polyphenol, and antioxidant capacity. Inadequate studies were there for the hot-air oven, microwave, microwave-convective and freeze drying kinetics of pineapple dehydration. In a precise experimental condition, the theoretical and empirical models could predict the pineapple drying well, though there was no general model that can describe the drying behaviour of pineapple slice during each drying method [14]. The ability of unsupervised learning and aptness for non-linear modeling are the key advantages of ANN.

The aim of the present study is to observe the effect of the hot-air oven, microwave, and microwave-convective and freeze drying on dehydration behaviour of sliced pineapple, to develop the drying kinetics model applying the ANN methodology, the effective moisture diffusivity and the rehydration characteristics of the dried product.

\section{Materials and methods}

Pineapples were bought from the local market of Jadavpur, West Bengal, India. After coring, they were cut into small pieces with a dimension of $2 \mathrm{~cm} \times 0.5 \mathrm{~cm} . \times 0.3 \mathrm{~cm}$ and dried as follows.

The convective drying ( $\mathrm{HA})$ was performed through using a hot air oven (Concepts International, Kolkata, India) at $60^{\circ} \mathrm{C}$ temperature till constant weight was achieved, it took $10 \mathrm{~h}$ of time to obtain the constant weight. The reading for weight loss was taken at 30 min interval for the entire period of drying. Microwave-assisted drying (MW) was performed by using a microwave (Samsung, Combi CE1031LAT, Mumbai, India) at $100 \mathrm{~W}$ till constant weight was achieved, it took 120 min of time to obtain the constant weight. The reading for the decline of weight was taken at 3 min interval for the entire period of drying. Microwave Convective drying (MWC) was performed by using a microwave (Samsung, Combi CE1031LAT, Mumbai, India) with convective heating at $40^{\circ} \mathrm{C}$ temperature $(600 \mathrm{~W})$ till constant weight was achieved, it took $96 \mathrm{~min}$ of time to obtain the constant weight. After every $2 \mathrm{~min}$, the reading for weight loss was recorded. After freezing (New Brunswick Scientific, England; Model no: C340-86) of samples for $22 \mathrm{~h}$ at $-30^{\circ} \mathrm{C}$, freeze drying (FD) was carried out by using a laboratory freeze dryer (FDU 1200, EYELA, Japan) at a pressure of $0.1 \mathrm{mBar}$ and temperature of $-40^{\circ} \mathrm{C}$. The reading for reduction of weight was taken at 45 min interval for the entire period of drying till constant weight was achieved, it took $20 \mathrm{~h}$ of time to attain equilibrium moisture content $(0.22 \mathrm{~kg}$ water $/ \mathrm{kg}$ dry basis) was attained from the initial moisture content of $(5.30 \mathrm{~kg}$ water/kg dry basis) [14].

The following equation was used to determine the moisture ratio (MR) during the drying of pineapple pulp.

$\mathrm{MR}=\frac{M-M_{e q}}{M_{\text {in }}-M_{e q}}$

where $M=$ moisture content of pineapple at time $\mathrm{t}(\mathrm{kg}$ water $/ \mathrm{kg}$ dry basis), $M_{\text {in }}=$ moisture content present in pineapple initially ( $\mathrm{kg}$ water/kg dry basis), $M_{\mathrm{eq}}=$ equilibrium moisture content of dried pineapple ( $\mathrm{kg}$ water/kg dry basis) [15].

Assuming temperature and effective moisture diffusivity remained constant throughout the drying process, shrinkage was negligible and change in moisture content was only due to diffusion, the equation for unsteady sate moisture diffusion of infinite slab [16] can be represented as follows.

$\mathrm{MR}=\frac{8}{\pi^{2}} \sum_{n=1}^{\infty} \frac{1}{(2 Z-1)^{2}} e^{\left[-\frac{\left.(2 Z-1)^{2} \pi^{2} D_{e} t\right)}{4 L^{2}}\right]}$

where $Z$ = positive integer, $D_{e}=$ effective moisture diffusivity $\left(\mathrm{m}^{2} / \mathrm{s}\right), \mathrm{L}=$ sample half thickness $(0.15 \mathrm{~cm}$.), the logarithmic form of first portion of the Eq. (5) can be expressed as:

$\ln (\mathrm{MR})=\ln \frac{8}{\pi^{2}}-\left(\frac{\pi^{2} D_{e} t}{4 L^{2}}\right)$

$D_{e}$ was determined from the plot of In (MR) against drying time $(t)$, considering the following equation:

$\mathrm{D}_{\mathrm{e}}=-\frac{\text { Slope } 4 L^{2}}{\pi^{2}}$ 
Rehydration ratio (RR) was determined as per the method described by Adiletta et al. [17] with little modification. $1 \mathrm{gm}$ of dried pineapple slice was dissolved in $10 \mathrm{gm}$ of water at three different temperatures of $20^{\circ} \mathrm{C}$, $40^{\circ} \mathrm{C}, 60^{\circ} \mathrm{C}$ and $80^{\circ} \mathrm{C}$, with continuous stirring for $20 \mathrm{~min}$. $\mathrm{RR}$ was calculated using the following equation.

$\mathrm{RR}=\mathrm{M}_{\mathrm{Rh}} / \mathrm{M}$

where $M_{R h}=$ mass of pineapple after rehydration (gm), $\mathrm{M}=$ mass of pineapple slice before rehydration (gm)

Coefficient of rehydration (CR) was measured through using the following equation:

$C R=M_{R h}\left(100-X_{0}\right) / M(100-X)$

where $X_{0}=$ moisture content of pineapple slice in wet basis, $X=$ moisture content of pineapple slice in wet basis. MATLAB R2014b (MathWorks Inc., USA) was used development of ANN model. The training set, test set and validation set were distributed in a ratio of 70:15:15.

\section{Results and discussion}

In the process of dehydration to reduce the moisture content initially from $5.30 \mathrm{~kg}$ water/ $\mathrm{kg}$ dry basis to $0.22 \mathrm{~kg}$ water $/ \mathrm{kg}$ dry basis, it was observed an absence of constant rate period for each drying method, rather the removal of moisture from pineapple slices was seen in the falling rate period. Dehydration kinetics for all the four drying methods is represented in Figs. 1 and 2. Having a uniform thickness of pineapple slices, distribution of temperature also seems to be even in case of thin-layer drying of the sample [18]. Water molecules exhibit a high rate of diffusion during the initial phase of drying, causes a fast rate of drying. This phenomenon can be explained on the basis of the theory that, moisture movement during the initial phase was governed by cell wall pathway and trans-membrane transport way.

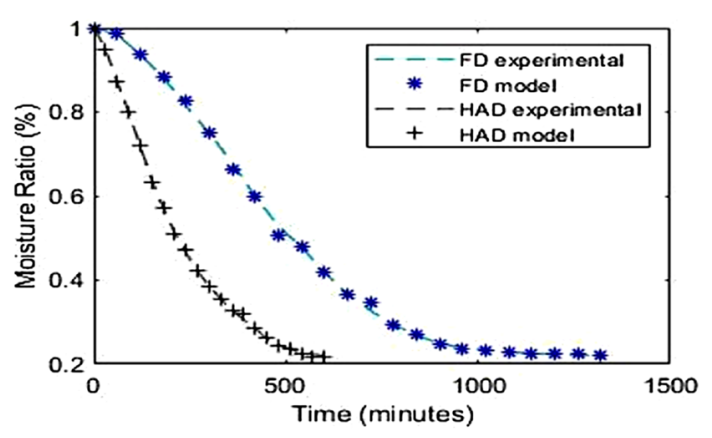

Fig. 1 Dehydration kinetics for freeze drying and hot air drying

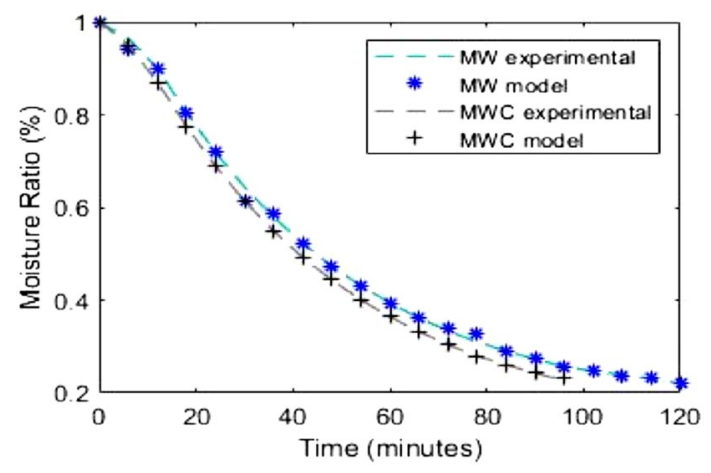

Fig. 2 Dehydration kinetics for microwave drying and microwave convective drying

The third phase of drying namely the falling rate period was characterized by a parameter called Effective moisture diffusivity $\left(D_{e}\right)$. For freeze drying $D_{e}$ value observed $24.30 \times 10^{-7} \mathrm{~m}^{2} / \mathrm{s}$ whereas $2823 \times 10^{-7} \mathrm{~m}^{2} / \mathrm{s}$ for microwave convective drying. In the case of microwave drying the intermediate $D_{e}$ value was $306.09 \times 10^{-7} \mathrm{~m}^{2} / \mathrm{s}$ while for hot air drying a lower value of $57.24 \times 10^{-7} \mathrm{~m}^{2} / \mathrm{s}$ was observed. So it is quite clear from the observations that there is a large variation of diffusivities with each mode of drying. This may be a result of a diversified approach of energy transmission to pineapple slices. Olanipekun et al. [4] and Izli et al. [13] found similar results for hot air, freeze, and microwave dried pineapple. Dielectric characteristics greatly influence the amount of moisture present within the pineapple slices.

Input for the hidden layer was determined from the following equation:

$I_{n_{1} n_{2}}=\sum_{n_{1}} P_{n_{1}} C_{n_{1} i}$

where $I_{n_{1} n_{2}}$ stands for hidden layer input criteria; $C_{n_{1} i}$ denoted as weightage between the input layer and hidden layer; $P_{n_{1}}$ referred to as a factor of input for $\mathrm{n}_{1}$ neuron. The following tan-sig transfer function was employed to process the neural network model:

$T_{f}=\frac{2}{1+\exp ^{-2 p}}-1$

The output of the hidden layer was calculated using the following expression:

$I_{n_{3} n_{2}}=\frac{2}{1+\exp ^{-2\left(I_{n_{1} n_{2}}+B\right)}}-1$

$I_{n_{3} n_{2}}$ and $B$ are defined as the hidden layer output criteria and bias amount respectively. The predicted moisture ratio was estimated by using the following equation: 
$M R_{n_{2}}=C_{i M R} I_{n_{3} n_{2}}+B_{M R}$

$M R_{n_{2}}$ referred to as predicted moisture ratio, $C_{i M R} I_{n_{3} n_{2}}$ denoted as weightage between output and hidden layer; $B_{M R}$ was the amount of bias for output.

The MR values attained from different drying methods at different intervals of time were distributed between training set, test set, and validation set in a ratio of 70:15:15.

To build the adequate kinetics model, 1000 numbers of iterations were performed. The rate of learning varied within the range of $0.5-0.9$. The neural network model for dehydration kinetics study was built of a 1 (input layer)- 9

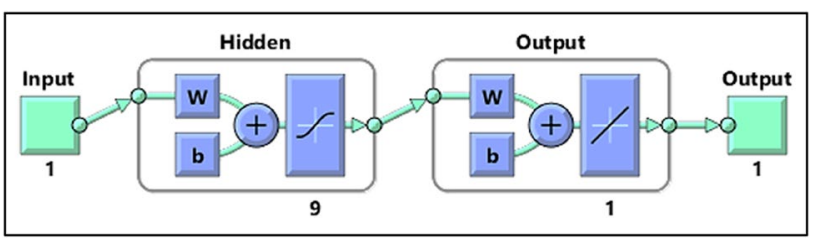

Fig. 3 Feedforward neural network
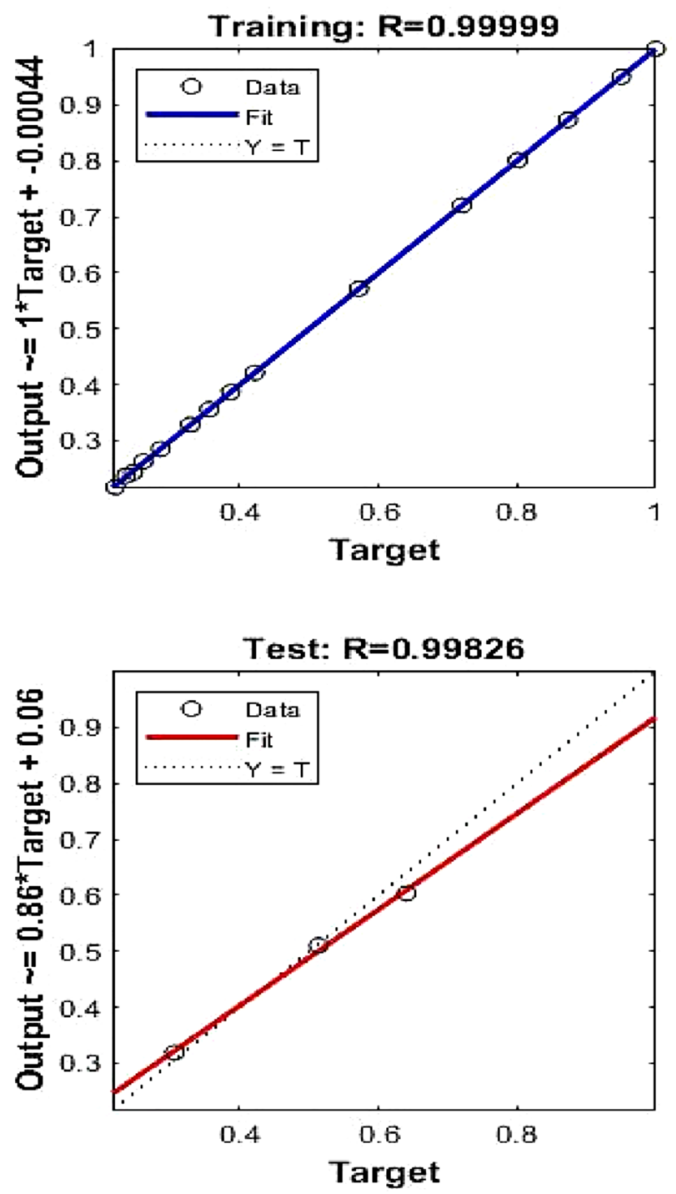

(hidden layer)-1 (output layer) configuration (Fig. 3). The Levenberg-Marquardt ANN tool for nonlinear activation function was employed along with ANN backpropagation algorithm for feed-forward neural network. The correlation coefficient (R) appeared as 1.000 (training), 0.99784 (testing), 0.99818 (validation) for best fitted HA model; 0.99999 (training), 0.99911 (testing), 0.99989 (validation) for best fitted MW model; 1.000 (training), 0.99943 (testing), 0.99939 (validation) for best fitted MWC model and 0.99995 (training), 0.99994 (testing), 0.99998 (validation) for best fitted FD model (Figs. 4, 5, 6 and 7). The ANN predicted versus experimental data set were plotted in Figs. 4, 5, 6 and 7 and marked as "All". The ANN model exhibited that experimental and predicted values of MR lie in close proximity for all the four drying techniques employed to dry pineapple slices. The coefficients of correlation (relative model prediction measurement) for $\mathrm{HA}, \mathrm{MW}, \mathrm{MWC}$, and FD were $0.99936,0.9994,0.99948$, and 0.99926 respectively. The root mean squared error (absolute model prediction measurement) for $\mathrm{HA}, \mathrm{MW}, \mathrm{MWC}$, and FD were $0.006,0.004,0.009$, and 0.074 respectively, implied the development of a robust model and competent prediction
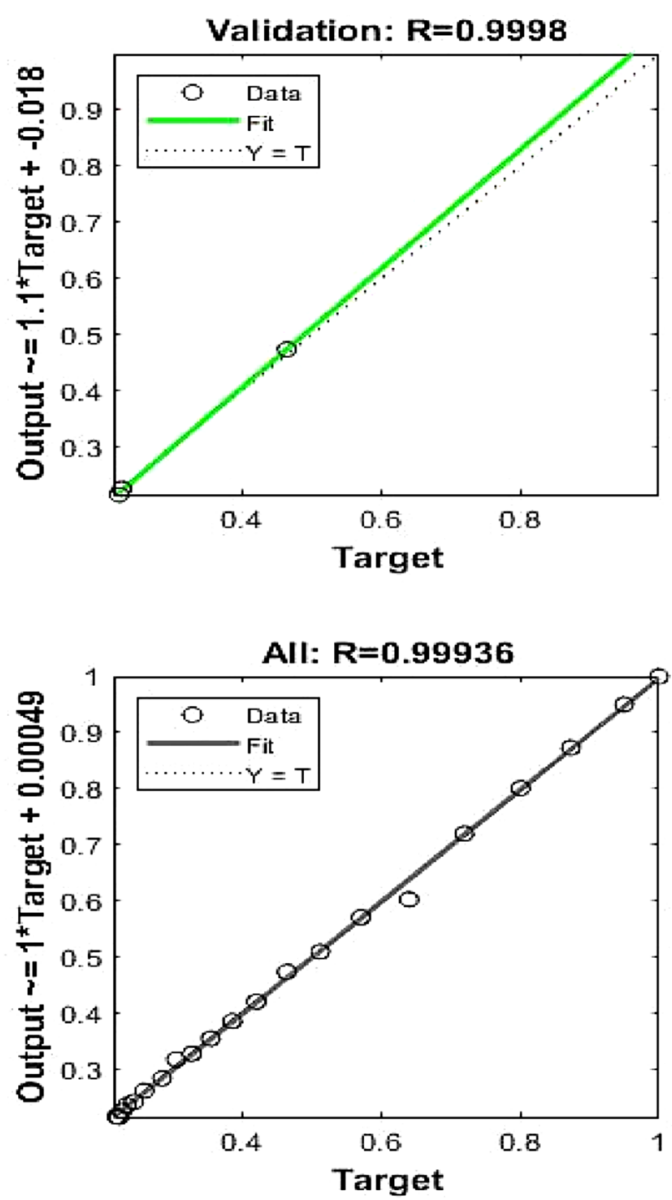

Fig. 4 Regression model of predicted and experimental data for hot air dried pineapple 

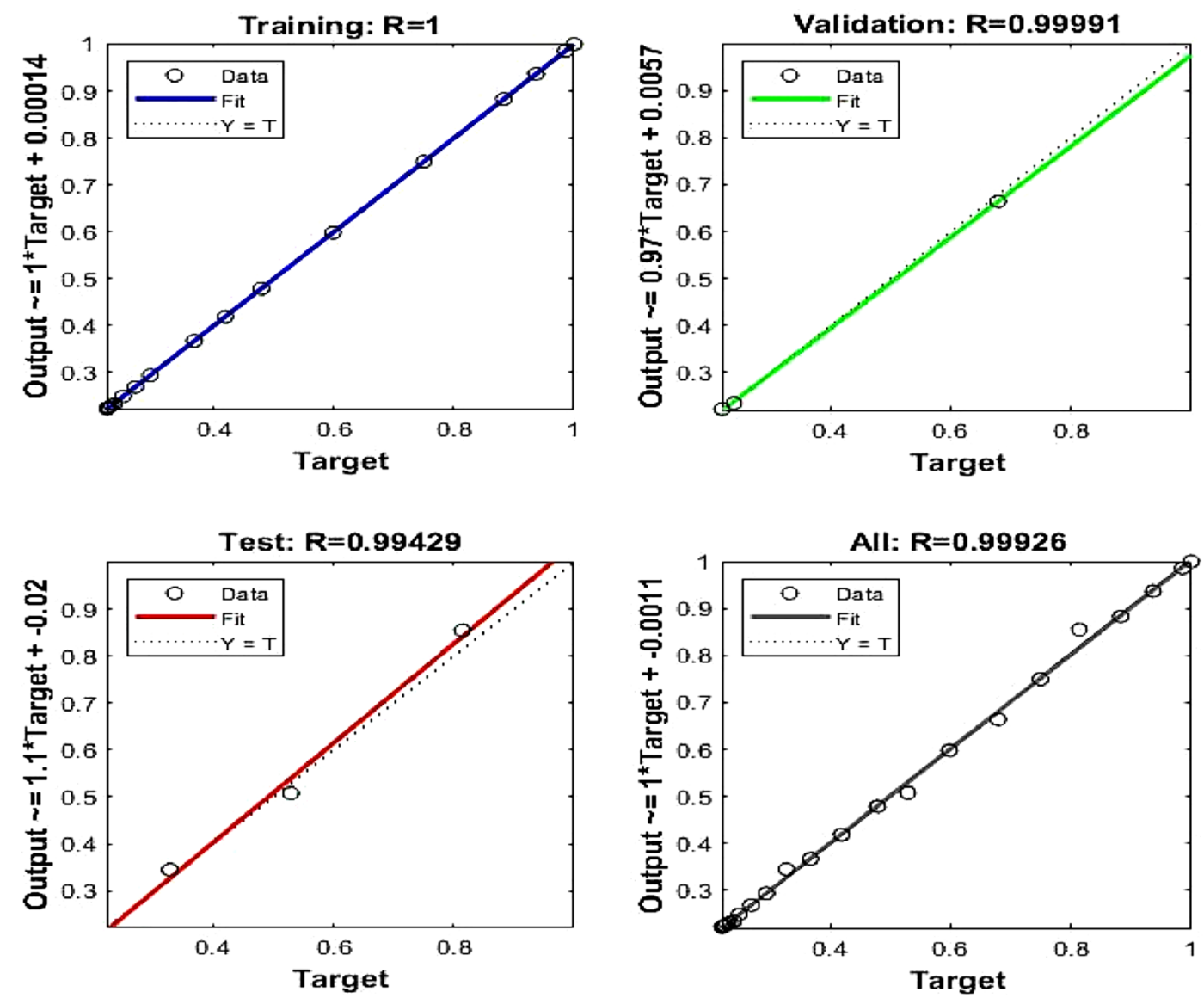

Fig. 5 Regression model of predicted and experimental data for freeze dried pineapple

ability of ANN model for dehydration kinetics of differently dried pineapple.

In the initial phase of hot air drying free moisture was removed from the surface of the pineapple slice, whereas, during the second stage the bound moisture was taking away from the sample. An increase in the coefficient of convective heat transfer between pineapple and air was mainly responsible to set the rate of drying [19]. With progression in microwave drying, the rate of drying became slower after the initial fast segment of drying. As the moisture content of pineapple decreased, a gradual depletion in microwave power absorption was there, which may reduce the rate of drying. Volumetric heating caused the pineapple slices to be dried out evenly. The moisture within the pineapple was heated up and evaporated, leading to the formation of a pressure gradient within the product which pumped up the moisture to the surface. For microwave drying of bael Dash et al. [7] also observed a similar phenomenon. In microwave convective drying, initially, the moisture present in the sample absorbs microwave energy lead to a fast rate of evaporation was there, which ultimately resulted in a higher rate of drying in the primary phase of pineapple drying. In the later stage, due to the unavailability of ample amount of free moisture the rate of drying declined, combined convective heat transfer along with microwave power was the dominant mode of drying in this phase, which collectively transferred the residual moisture available within the pineapple slice to the surface [20]. In the falling rate period of freeze drying, due to the gradual downward movement of the sublimation front, it ultimately extended to the lower surface of the sample, ensued a resistance in moisture and heat transfer process. Conduction of heat energy occurred through the frozen pineapple layer followed by the dried pineapple layer. The sublimation process was also got affected by the interaction of polar compounds present in the pineapple with the residual moisture. In the later part of drying, water vapour diffused through the porous textured sample and traversed a relatively long path to reach the surface, which hindered the process of mass transfer [21].

For any dried food product the utmost factors to be considered are quality and physicochemical properties of it. Therefore it is necessary to know which factors control 

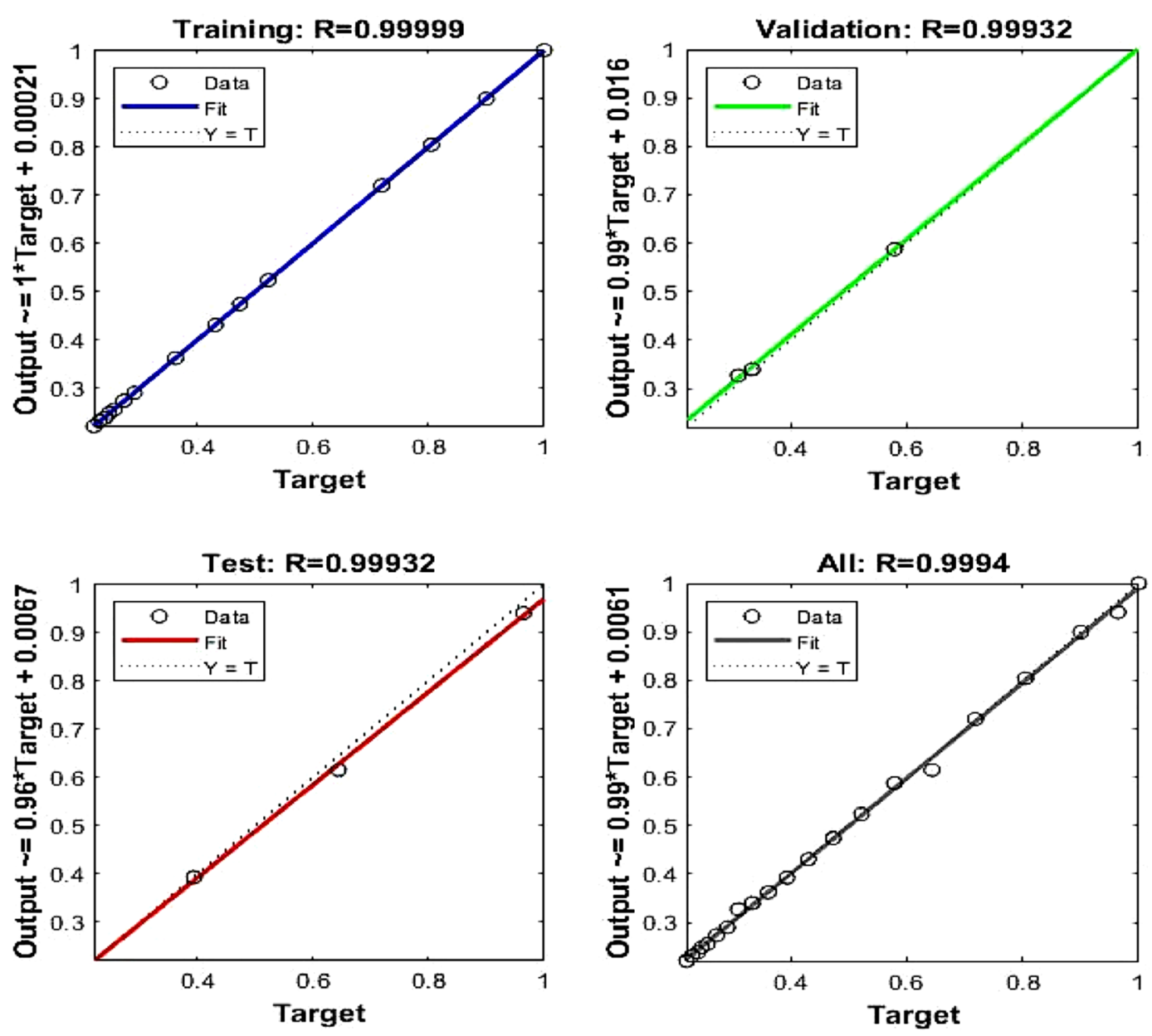

Fig. 6 Regression model of predicted and experimental data for microwave dried pineapple

these properties. Rehydration characteristics have been found to be a crucial factor in controlling these properties of dried product [22]. In consequences of moisture removal during the drying period, the capillary space became narrow, shrinkage of cells occurred and moreover, the contraction was observed in cellular material which leads to disintegrating the vegetal tissue. In drying a high RR indicates cell damage to a smaller extent. Cell damage seems to be less with a high value of RR [23]. RR depends largely on the drying methods used and its value gained a minimum of 2.00 for MWC whereas it was attained a maximum of 5.49 for FD. For FD, as it contained a relatively larger number of pores, more amount of water adhered to the sample which in turn gives rise to the highest RR value of 5.49 at $80^{\circ} \mathrm{C}$. Gaware et al. [24] observed similar results for freeze dried tomato slice. Dehydrated tissue regained moisture in course of rehydration and therefore tried in obtaining the original structure owing to its natural elasticity property. But microwave raptured the cellular structure, maybe due to this reason, comparatively lower RR was observed in the case of MW. Argyropoulos et al. [25] reported similar observations for rehydration of dried mushroom. In contrast, it has also been observed an increased RR value of MW compared to HA, MWC sample. The reason for this observation may be stated as the water molecules penetrate through the void spaces created by microwave within the adjoining cell. A similar observation was reported by Ozcan-sinir et al. [22]. MWC being the fastest drying method employed for pineapple slices in this study, resulted in irreversible cellular shrinkage, which may responsible for hindrance in water uptake during rehydration operation. Mohanta et al. [26] observed similar rehydration characteristics for microwave convective dried ginger. An increase in RR was noted with increasing rehydration temperature from 20 to $80^{\circ} \mathrm{C}$, this may be supported by the fact that with a rise in temperature, moisture also penetrated to the dried product at a higher rate. Balasbramanian et al. [27], Doymaz et al. [23] and Mujaffar et al. [28] found similar observation for rehydration of dried betel leaves, mushroom slices, and amaranth leaves. For FD pineapple slices at $80^{\circ} \mathrm{C}$ a maximum value of 0.969 was reported in terms of $C R$ whereas the minimum value 

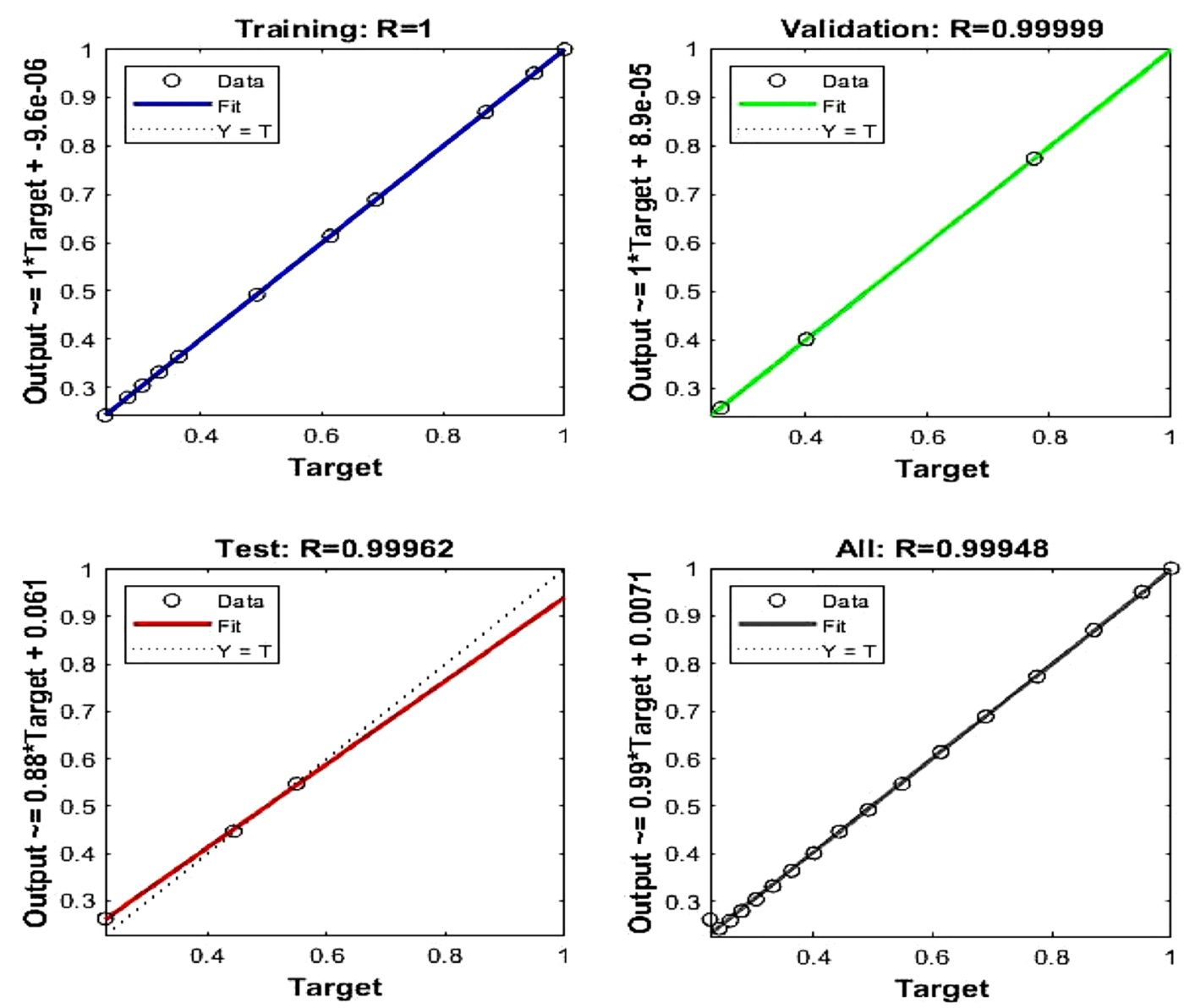

Fig. 7 Regression model of predicted and experimental data for microwave-convective dried pineapple

of 0.369 was observed at $20^{\circ} \mathrm{C}$ for MWC pineapple slices (Table 1).

\section{Conclusion}

The ANN model was developed for differently dried pineapple slice considering the Levenberg-Marquardt algorithm. From the coefficient of correlation, it was evident that all four models could predict the dehydration kinetics of pineapple efficiently. In terms of drying time required, microwave convective was the most efficient one, produced the desired product in only $96 \mathrm{~min}$, while freeze drying consumed maximum time $(20 \mathrm{~h})$. All four drying kinetics were commenced in the falling rate period. The Effective moisture diffusivity $\left(D_{e}\right)$ was highest for microwave convective drying $\left(2823 \times 10^{-7} \mathrm{~m}^{2} / \mathrm{s}\right)$ followed by microwave drying $\left(306.09 \times 10^{-7} \mathrm{~m}^{2} / \mathrm{s}\right)$, hot air drying $\left(57.24 \times 10^{-7} \mathrm{~m}^{2} / \mathrm{s}\right)$ and freeze drying $\left(24.30 \times 10^{-7} \mathrm{~m}^{2} / \mathrm{s}\right)$. The maximum RR was observed for FD at $80^{\circ} \mathrm{C}$, while the minimum was for MWC (2.00) at $20^{\circ} \mathrm{C}$. The FD sample with fluffy and porous texture absorbed more water molecules, whereas, moisture
Table 1 Rehydration ratio and coefficient of rehydration for microwave convective dried, hot air dried, microwave dried and freeze dried pineapple at different temperature

\begin{tabular}{llll}
\hline Sample & $\begin{array}{l}\text { Tempera- } \\
\text { ture }\left({ }^{\circ} \mathrm{C}\right)\end{array}$ & $\begin{array}{l}\text { Rehydration } \\
\text { ratio (RR) }\end{array}$ & $\begin{array}{l}\text { Coefficient of } \\
\text { rehydration }(\mathrm{CR})\end{array}$ \\
\hline Microwave convective & 20 & 2.00 & 0.369 \\
dried (MWC) & 40 & 2.52 & 0.420 \\
& 60 & 2.97 & 0.486 \\
Hot air dried (HA) & 80 & 3.21 & 0.585 \\
& 20 & 3.03 & 0.522 \\
& 40 & 3.48 & 0.633 \\
Microwave dried (MW) & 20 & 3.72 & 0.702 \\
& 60 & 3.90 & 0.801 \\
Freeze dried (FD) & 40 & 4.01 & 0.720 \\
& 60 & 4.39 & 0.774 \\
& 80 & 4.62 & 0.831 \\
& 20 & 4.50 & 0.807 \\
& 40 & 4.86 & 0.873 \\
& 60 & 5.28 & 0.915 \\
& 80 & 5.49 & 0.969
\end{tabular}


penetration was less susceptible in MWC due to permanent cell damage. The effect of drying parameters like air flow rate, temperature, microwave power levels, and extent of vacuum may alter the dehydration and rehydration properties of dried products. Neuro-fuzzy systems may be an alternative approach to build dehydration kinetics models which can further be explored.

\section{Compliance with ethical standards}

Conflict of interest Authors declare no conflict of interest.

\section{References}

1. Sarkar T, Nayak P, Chakraborty R (2018) Pineapple [Ananas comosus (L.)] product processing techniques and packaging: a Review. IIOABJ 9(4):6-12

2. Ramallo LA, Mascheroni RH (2012) Quality evaluation of pineapple fruit during drying process. Food Bioprod Process 90:275283. https://doi.org/10.1016/j.fbp.2011.06.001

3. FAO (2018) Food and agricultural organization statistical database. http://www.fao.org/faostat/en/\#data/QC

4. Olanipekun B, Tunde-Akintunde T, Oyelade O, Adebisi M, Adenaya T (2015) Modeling of pineapple drying. J Food Process Preserv 39:1431-1441. https://doi.org/10.1111/jfpp.12362

5. Sarkar T, Salauddin M, Hazra SK, Chakraborty R (2020) Comparative study of predictability of response surface methodology (RSM) and artificial neural network-particle swarm optimization (ANN-PSO) for total colour difference of pineapple fortified rasgulla processing. Int J Intell Netw 15:17-31. https://doi. org/10.1016/j.jijin.2020.06.001

6. Kumar V, Sharma HK, Singh K (2016) Mathematical modelling of thin layer microwave drying of taro slices. J Inst Eng Ser A 97(1):53-61. https://doi.org/10.1007/s40030-016-0147-1

7. Dash K, Chakraborty S, Singh Y (2020) Modeling of microwave vacuum drying kinetics of Bael (Aegle marmelos L.) pulp by using artificial neural network. J Inst Eng Ser A. https://doi. org/10.1007/s40030-020-00431-x

8. Yazdani M, Borghaee AM, Rafiee S, Minaei S, Beheshti B (2013) Mathematical and neural networks modelling of thin-layer drying of peach (Prunus persica) slices and their comparison. Eur J Exp Biol 3(3):712-721

9. Azeez L, Adebisi SA, Oyedeji AO, Adetoro RO, Tijani KO (2019) Bioactive compounds' contents, drying kinetics and mathematical modelling of tomato slices influenced by drying temperatures and time. J Saudi Soc Agric Sci 18(2):120-126. https://doi. org/10.1016/j.jssas.2017.03.002

10. Nicoleti JF, Telis-Romero J, Telis VRN (2001) Air-drying of fresh and osmotically pre-treated pineapple slices: fixed air temperature versus fixed slice temperature drying kinetics. Dry Technol 19(9):2175-2191. https://doi.org/10.1081/DRT-100107493

11. Agarry SE, Ajani AO, Aremu MO (2013) Thin layer drying kinetics of pineapple: effect of blanching temperature-time combination. Nigerian J Basic Appl Sci 21(1):1. https://doi.org/10.4314/ njbas.v21i1.1

12. Óscar R, Wesley G, Sueli R, Fabiano ANF (2017) Effect of acoustically assisted treatments on vitamins, antioxidant activity, organic acids and drying kinetics of pineapple. Ultrason Sonochem 35:92-102. https://doi.org/10.1016/j.ultsonch.2016.09.006
13. Izli N, İzli G, Taşkın O (2018) Impact of different drying methods on the drying kinetics, color, total phenolic content and antioxidant capacity of pineapple. CyTA J Food 16:213-221. https://doi. org/10.1080/19476337.2017.1381174

14. Bai J, Xiao H, Ma H, Zhou C (2018) Artificial neural network modelling of drying kinetics and color changes of ginkgo biloba seeds during microwave drying process. J Food Qual. https:// doi.org/10.1155/2018/3278595

15. Arslan D, Özcan M (2010) Study the effect of sun, oven and microwave drying on quality of onion slices. LWT Food Sci Technol 43:1121-1127. https://doi.org/10.1016/j.lwt.2010.02.019

16. Demiray $E$, Şeker A, Tulek $Y$ (2016) Drying kinetics of onion (Allium cepa L.) slices with convective and microwave drying. Heat Mass Transf 53:1-11. https://doi.org/10.1007/s0023 1-016-1943-x

17. Adiletta G, Wijerathne C, Senadeera W, Russo P, Crescitelli A, Matteo MD (2018) Dehydration and rehydration characteristics of pretreated pumpkin slices. Ital J Food Sci 30(4):684-706. https ://doi.org/10.14674/IJFS-1176

18. Onwude DI, Hashim N, Janius RB, Nawi NM, Abdan K (2016) Modeling the thin-layer drying of fruits and vegetables: $a$ review. Compr Rev Food Sci Food Saf 15:599-618. https://doi. org/10.1111/1541-4337.12196

19. Chasiotis VK, Tzempelikos DA, Filios AE, Moustris KP (2019) Artificial neural network modelling of moisture content evolution for convective drying of cylindrical quince slices. Comput Electron Agric. https://doi.org/10.1016/j.compag.2019.105074

20. Yildiz G, İzli G (2018) Influence of microwave and microwaveconvective drying on the drying kinetics and quality characteristics of pomelo. J Food Process Preserv. https://doi.org/10.1111/ jfpp. 13812

21. Wang W, Wang S, Pan Y, Yang J, Zhang S, Chen G (2019) Porous frozen material approach to freeze-drying of instant coffee. Dry Technol 37(16):2126-2136. https://doi.org/10.1080/07373 937.2018.1564759

22. Sinir GO, Karabacak AÖ, Tamer C, Copur O (2018) The effect of hot air, vacuum and microwave drying on drying characteristics, rehydration capacity, color, total phenolic content and antioxidant capacity of Kumquat (Citrus japonica). Food Sci Technol (Campinas) 39(2):475-484. https://doi.org/10.1590/fst.34417

23. Doymaz i (2014) Drying kinetics and rehydration characteristics of convective hot-air dried white button mushroom slices. J Chem 2014:1-8. https://doi.org/10.1155/2014/453175

24. Gaware TJ, Sutar N, Thorat BN (2010) Drying of tomato using different methods: comparison of dehydration and rehydration kinetics. Dry Technol 28(5):651-658. https://doi. org/10.1080/07373931003788759

25. Argyropoulos D, Heindl A, Müller J (2011) Assessment of convection, hot-air combined with microwave vacuum and freezedrying methods for mushrooms with regard to product quality. Int J Food Sci Technol 46:333-342. https://doi.org/10.111 1/j.1365-2621.2010.02500.x

26. Mohanta B, Dash SK, Panda MK, Sahoo GR (2014) Standardization of process parameters for microwave assisted convective dehydration of ginger. J Food Sci Technol 51(4):673-681. https ://doi.org/10.1007/s13197-011-0546-2

27. Balasubramanian S, Sharma R, Gupta R, Patil R (2011) Validation of drying models and rehydration characteristics of betel (Piper betel L.) leaves. J Food Sci Technol 48:685-691. https://doi. org/10.1007/s13197-010-0188-9

28. Mujaffar S, Loy A (2016) The rehydration behavior of microwavedried amaranth (Amaranthus dubius) leaves. Food Sci Nutr 5(3):399-406. https://doi.org/10.1002/fsn3.406

Publisher's Note Springer Nature remains neutral with regard to jurisdictional claims in published maps and institutional affiliations. 